\title{
Estimating stream piracy in the lower Ganga Plain of a Quaternary geological site in West Bengal, India applying sedimentological bank facies, log and geospatial techniques
}

\author{
B. Bera ${ }^{1, *}$, S. Bhattacharjee ${ }^{2}$ and C. Roy $^{3}$ \\ ${ }^{1}$ Department of Geography, Sidho-Kanho-Birsha University, Ranchi Road, P.O. Purulia Sainik School 723 104, India \\ ${ }^{2}$ Department of Geography, Jogesh Chandra Chaudhuri College (Calcutta University), 30, Prince Anwar Shah Road, Kolkata 700033 , India \\ ${ }^{3}$ Department of Geography, University of Gour Banga, Mokdumpur, Malda 732 103, India
}

River Bhagirathi is a distributary channel of River Ganga, and Babla is one of its right-bank tributaries in the Ganga delta plain. The Bhagirathi flows in a meandering pattern through the New Quaternary alluvium plain, whereas the Babla flows through the Old Quaternary deposits of yellowish-brown sand, silt and clay. As the Bhagirathi is a distributary of River Ganga, it brings in million tonnes of sediments annually. Mid-channel bar formation, bar dynamics and non-cohesive nature of bank materials promote bank failure and rapid shifting of the channels in the Newer Quaternary sites. As the Bhagirathi migrates towards River Babla, the interfluve zone is being progressively engulfed by the course of the former. To estimate the stream piracy or capture, bank materials, internal organization of mid-channel bar, flow parameters (velocity, channel depth, discharge, etc.) have been taken into consideration. This study documents changes in channel morphology and hydrological parameters, dynamic morphology and hydrological regime of the fluvial system from 1852 to 2017 . It predicts the actual time when the Bhagirathi will capture River Babla near village Natungram. The study also discusses why in recent years the rate of lateral migration has increased for a particular portion on the right bank of River Bhagirathi near Natungram.

Keywords: Bank materials, geospatial technique, interfluves, quaternary sites, stream piracy.

AVULSION is a process of shifting of spatial pattern of a distributary river channel to a newer flow path on a floodplain surface ${ }^{1}$, which is considered as an important fluvio-environmental hazard in densely populated areas ${ }^{2}$. More commonly, avulsion occurs when a stretch of any river has crossed the critical value or 'avulsion threshold $^{3}$ and the shifting or migration of a reach of the river course influences the morphology, water and sediment distribution load and the configuration of fluvial

*For correspondence. (e-mail: biswajitbera007@gmail.com) deposits $^{4-8}$. The dynamic morphology, rate of sedimentation and evolution of floodplains as well as channel-bed configuration are controlled by various factors. The magnitude of avulsion may vary gradually or abruptly over the existing floodplain depending on the aggradation rate. Although varying aggradation processes and existing floodplain geomorphological signatures like palaeo channel, meander scrollbar, spill channel and tectonic events may also accelerate avulsion ${ }^{9-13}$. Several spatio-temporal and hydro-geomorphological studies in the South American rivers (e.g. River Amazon, River Rio Negro, Solimoes River, Upper Parana and Araguaia River) have also highlighted neotectonic activity and its effect on river morphology; the ultimate consequence is channel avulsion ${ }^{14-18}$. However, channel avulsion can be explained as a normal floodplain process in most rivers of the world, rather than the result of a tectonic event ${ }^{19,20}$. Stratigraphic evolution of floodplains, geomorphological setting and hydrological regime of fluvial systems are regulated by tectonic activities through a much longer geological timescale.

Broadly, river discharge, huge amounts of sediment yield and supply accelerate and modify floodplain geomorphological set-up, channel avulsion and channel-bed configuration in Quaternary alluvial sites in tropical regions. Floodplain evolution, alluvial chronology, sediment supply, sediment depth, grain size and stratigraphic correlation of infill should be analysed to understand the geographic as well as economic importance of floodplains ${ }^{1}$. Tropical monsoon or devastating floods bring a large amount of sediments to the floodplain surface and reshape the architecture of the deposit. But the rate of lateral stream migration is not uniformly following the geomorphic scale on Quaternary alluvial sites (in tropical regions). Geomorphic complications are more common in tropical alluvial plains and dynamic fluvial mechanism simulates different landforms and process irregularities.

River capture or river piracy/hijack is defined as diversion of part of the course or small river by another strong and active river. In fluvial geomorphology, captor streams are defined as those that capture another weaker 
stream, whereas the latter is known as the captured stream. During old and mature stage, river capture occurs through the process of meander cut-off and lateral migration. Repeated avulsion or channel shifting has been evidenced at different positions along River Indus within the Indian subcontinent due to devastating earthquakeinduced faulting ${ }^{1}$. In the 18th century, the biggest earthquake triggered the shifting of River Brahmaputra 80 $100 \mathrm{~km}$ to the west due to upliftment of land surface ${ }^{21}$. The upper part of River Ganga once avulsed due to a tectonic event ${ }^{22}$.

River Bhagirathi (190 km length) is a distributary channel of River Ganga (Figure 1), which is bifurcated near Mithipur, Murshidabad district, South Bengal; it flows in the southern direction and is finally discharged into the Bay of Bengal. River dynamics are common fluvio-hydrological features within the Ganga plain but most significantly evident in the eastern part of the Ganga plain and several river shifting/migration and floodplain geomorphological features have also been developed and reshaped due to catastrophic flood ${ }^{2,5,19}$. During 1764 2007 River Ganga and its fluvial dynamics have been thoroughly studied between Rajmahal and Jalangi, and the Government of India framed some policies for societal benefits ${ }^{23}$

In 1857, the East India Company appointed Captain Sherwill to assess the fluvio-dynamic condition of River Hooghly. It has been reported that River Ganga previously flowed through the present course of the BhagirathiHooghly $^{24}$. The off-take of River Bhagirathi has been shifted from Dhulian to Nayansukh, Aurangabad, Suti,

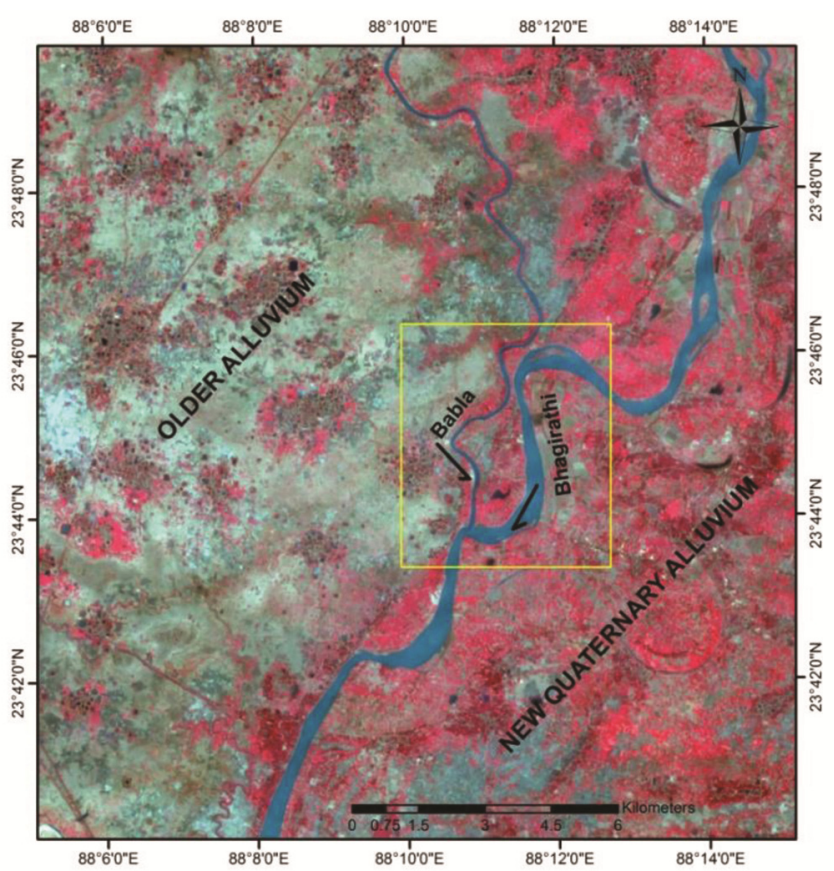

Figure 1. Location of study area showing flow path of River Bhagirathi and River Babla along with Old and New Quaternary alluvium deposit sites.
Mithipur, Khejurtala during consecutive years (Figure 2). In recent years, the off-take of River Bhagirathi is situated at Khejurtala, Mithipur ${ }^{23,25}$. Due to shortage of water and rapid rate of siltation, the off-take is now exposed on the surface during pre-monsoonal months, beyond the Jangipur barrage. The hydraulic gradient of the off-take stretch clearly indicates that the channel gradient is towards the parent River Ganga-Padma. To rejuvenate the Bhagirathi, feeder canal is linked with the river near Ahiron at Murshidabad. River Bhagirathi also gets higher volume of water during monsoonal months (June to September) from its left and right bank tributaries. River-bank erosion, flood and water inundation are dominant monsoonal features in the neighbouring districts along the river.

River Dwarka, whose lower part is better known as Babla, originates in Santhal Parganas, Jharkhand. The river maintains its flow through Birbhum and Murshidabad districts to finally confluence with the Bhagirathi at Kalyanpur Ghat in Salar (after the confluence of Dwarka and Mayurakshi, the joint flow is called Babla). Kopai, Brahmani and Bakreshwar are some tributaries of River Mayurakshi, while Banki and Gamvira are significant tributaries of River Dwarka. These two major river systems (Mayurakshi and Dwarka) contribute water with sediments to River Babla, and finally it flows into the Bhagirathi. The total area of Dwarka river basin is $3569.76 \mathrm{sq}$. $\mathrm{km}$ and it is fed by water and sediments of its tributaries. Flowing over the plain region, the river also experienced a meandering flow path. Old maps and satellite imagery prominently show the Bhagirathi approaching River Babla (west) near village Natungram through lateral erosion and channel avulsion. Newly avulsed river banks have less vegetation, which increases bank instability, and the resultant channel shifting creates continuous bank failure or bank erosion ${ }^{26}$. Continuous bank failures culminate into destructive fluvio-hydrological hazards ${ }^{27}$. To estimate stream piracy or river capture on quaternary alluvium deposit sites or interfluve between the Bhagirathi and Babla rivers, specific objectives/research questions have been raised: (i) to predict the actual time when River Bhagirathi will capture the lower stretch of River Babla; (ii) why in recent years the rate or degree of lateral erosion or shifting is tremendously increasing at a particular portion of Natungram or right bank of River Bhagirathi; (iii) to analyse the role of mid-channel bar and its gradual evolution influencing lateral migration, as well as the consequences on human habitation.

\section{Materials and methods}

\section{Data generation through RS and GIS techniques}

Historical evolution of the interfluve region or more specifically to study fluvial dynamics and probability of 


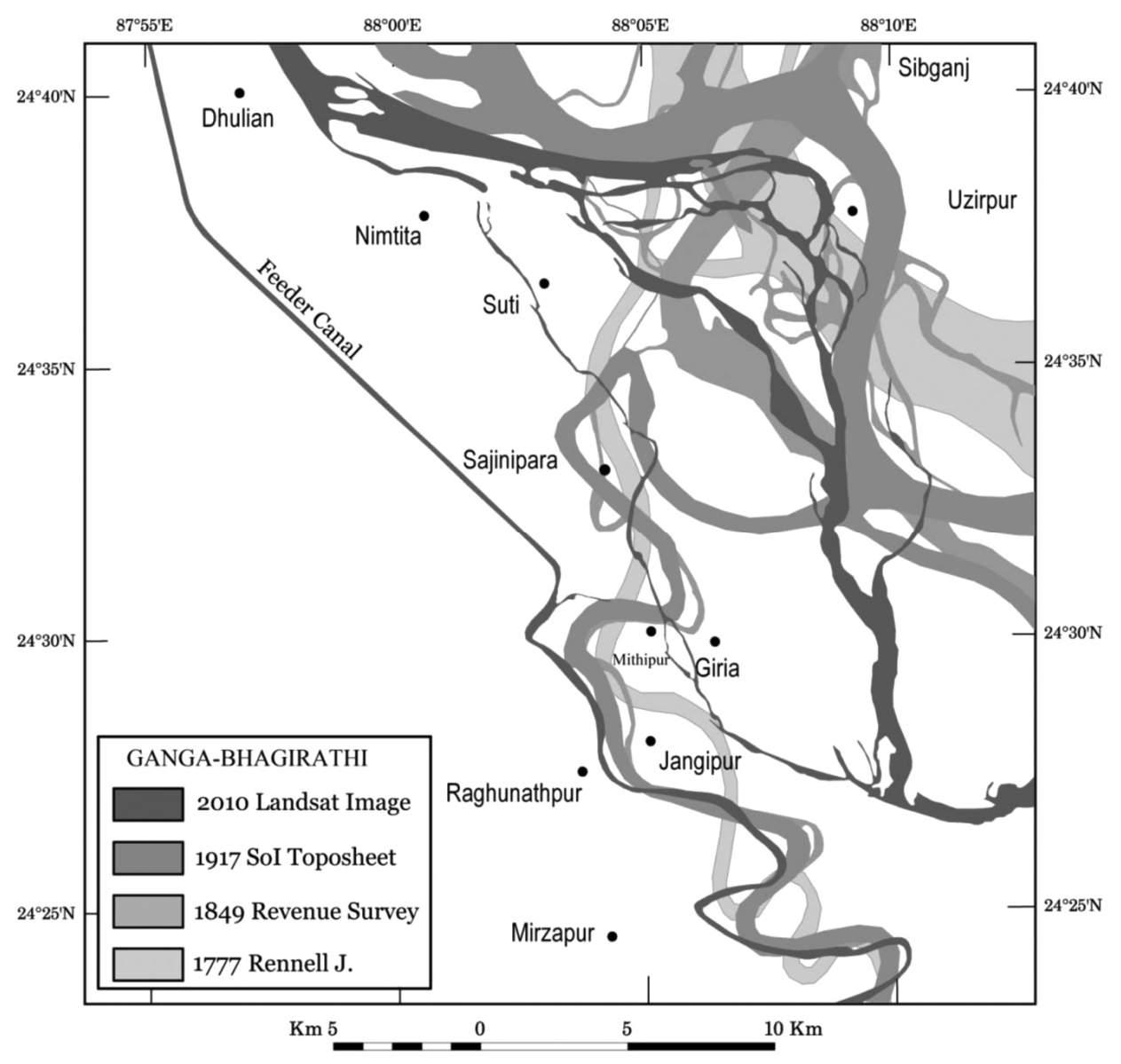

Figure 2. Map of changing off-take of the River Bhagirathi (Source: ref. 25).

stream piracy, various old maps and satellite images have been used. Images are collected from United States Geological Survey (USGS) Earth Explorer (Table 1). Only post-monsoonal images of the study area have been collected in order to get prominent depositional features within the channel. Satellite images are collected from USGS Earth Explorer for the geospatial study of River Bhagirathi and River Babla in different years. Images are further reprojected into projected coordinate system from geographic coordinate system for better accuracy and geometrical assessment. UTM projection has been considered for all the images and maps (district map, revenue survey map) on WGS 84 datum platform. Spatial data which are relevant to the study are also expressed using projected coordinate systems (PCS). Finally, the coordinates are expressed using linear measurements rather than angular degrees. Orthorectification has been done on the satellite images to eliminate sensor distortion. The resultant orthorectified image has a constant scale from where the feature identification has been done with accurate geometry. Atmospheric errors of the satellite images have been eliminated by atmospheric correction method in Erdas Imagine software. The algorithm is given here for better understanding.

$$
L_{\mathrm{s}}=L_{\mathrm{tot}} \rho T+L_{\mathrm{p}}
$$

where $L_{s}$ is the energy recorded by the sensor, $L_{\text {tot }}$ the total incident energy in a specific spectral band, $\rho$ the ratio of incident to reflected energy, $T$ the atmospheric transmittance and $L_{\mathrm{p}}$ is the path irradiance in a specific spectral band.

Vector data models are prepared on the raster layers (maps and images) using ArcGIS 10.3 software. The vector datasets are further analysed for change detection, and linear measurements (such as length of the river, width, minimum distance of interfluve) have also been done.

\section{Fluvio-hydrological methods and instrumentation}

Various fluvio-hydrological parameters have been considered to measure fluvial dynamics as well as magnitude of migration of the Bhagirathi and Babla rivers. Detailed discussion is given below.

Sinuosity index has been measured digitally from Revenue Survey Map (1875), US Army map (1955) and satellite images (1973, 1991, 2000, 2009, 2016 and 2017) to obtain deviation over the course of time of River 
RESEARCH ARTICLES

Table 1. Topographic maps and remote sensing images with their multiple attributes

\begin{tabular}{|c|c|c|c|c|}
\hline Data type & Satellite/sensor/map number & $\begin{array}{l}\text { Acquisition date } \\
\text { (dd.mm.yy) }\end{array}$ & $\begin{array}{l}\text { Spatial resolution/ } \\
\text { map scale }\end{array}$ & Source \\
\hline Topographic maps & $\begin{array}{l}\text { District map of Moorshedabad, Lower Province, Bengal } \\
\text { NF } 45-3\end{array}$ & $\begin{array}{l}1875 \\
1955\end{array}$ & $\begin{array}{l}1 \text { inch }=4 \text { mile } \\
1: 250,000\end{array}$ & $\begin{array}{l}\text { Revenue Survey Map } \\
\text { US Army Map Service }\end{array}$ \\
\hline $\begin{array}{l}\text { Remote sensing } \\
\text { images }\end{array}$ & $\begin{array}{l}\text { LANDSAT 1-MSS (Multispectral Scanner) } \\
\text { LANDSAT 4-TM (Thematic Mapper) } \\
\text { LANDSAT 7-ETM + (Enhanced Thematic Mapper Plus) } \\
\text { LANDSAT 7-ETM + (Thematic Mapper) } \\
\text { LANDSAT 8-OLI (Operational Land Imager) } \\
\text { LISS III (BAND } 3: 2: 1)\end{array}$ & $\begin{array}{l}28.11 .1973 \\
18.2 .1991 \\
11.11 .2000 \\
9.11 .2009 \\
8.11 .2016 \\
2017\end{array}$ & $\begin{array}{l}60 \mathrm{~m} \\
30 \mathrm{~m} \\
30 \mathrm{~m} \\
30 \mathrm{~m} \\
30 \mathrm{~m} \\
23.5 \mathrm{~m}\end{array}$ & $\begin{array}{l}\text { USGS } \\
\text { USGS } \\
\text { USGS } \\
\text { USGS } \\
\text { UGGS } \\
\text { USGS }\end{array}$ \\
\hline
\end{tabular}

Bhagirathi and River Babla within the study area ${ }^{28}$. Depth of the channels is measured by dipping iron ball method from a floating boat. Data regarding velocity and depth have been collected by extensive field surveys during monsoon and post-monsoon seasons since 2000, followed by the years 2009, 2012, 2015 and 2017 at Kalyanpur Ghat and Chargobalpur. Based on the cross profiles of the two rivers, wetted perimeter and cross-sectional area have been calculated. Hydraulic radius is calculated from the above parameters (cross-sectional area and wetted perimeter of Kalyanpur and Chargobalpur) to determine the channel condition and efficiency. Digital current meter is used to measure the velocity $(\mathrm{m} / \mathrm{s})$ of both rivers at different points across the cross-section. Surface velocity (within $1 \mathrm{~m}$ depth) of different points along the crosssection is measured for both the rivers in different seasons. Based on the velocity data across the cross-section, arithmetic average is calculated. Discharge is calculated by multiplying cross-sectional area and average velocity of the measured cross-sections at Kalyanpur Ghat and Chargobalpur for both the rivers. Multiple observations of fluvial parameters have been made during monsoonal and post-monsoonal months. Subsequently, arithmetic average of discharge has been calculated based on season-wise multiple data. Various water samples have been collected from the surface to measure the amount of suspended sediments. After settling of the sediments, water samples are filtered and dry weight of the sediments $(\mathrm{mg} / \mathrm{l})$ is measured using a weigh machine in the laboratory.

\section{Sedimentary bank facies and log analysis}

Right bank facies study of the Bhagirathi was conducted in 2017 during post-monsoon (December). A prominent $2 \mathrm{~m}$ natural bank was studied at Natungram (interfluve region), which is exposed due to continuous bank failure. We have identified different micro-sedimentary structures like laminations, bioturbation, etc. Sediment sample was also collected from different layers to study textural characteristics of the soil. Facies studies were conducted for a mid-channel bar at five different points (bar head, bar tail, right bar margin, left bar margin and mid bar), and the internal organization was documented by the construction of sedimentological logs. In December 2017, an area of $1 \mathrm{sq} . \mathrm{m}$ with $1 \mathrm{~m}$ depth was excavated at five sites. This study reflects the nature of deposition of the sediments, stability and shifting direction. Excavation was not possible beyond $1 \mathrm{~m}$ depth due to wet and dripping subsurface hydrological conditions. Sedlog 3.1 software was used to make log profiles of the bar.

\section{Results and discussion}

\section{Geological setting and bank facies study}

River Bhagirathi divides Murshidabad district into two distinct physiographic units: (i) the area situated to the west of the Bhagirathi is an upland which stands above the recent floodplain having elevation range $15-35 \mathrm{~m}$ amsl; (ii) the area situated east of the Bhagirathi is a flat land with elevation $8-16 \mathrm{~m}$ amsl. The area on the western part of the Bhagirathi is mainly covered by a sequence of older Quaternary alluvium deposits by the river systems of Dwarka (Babla)-Mayurakshi-AjayDamodar. The sequences of Quaternary deposits are characterized by yellowish-brown sand, silt and clay. The post-monsoon river bank stratification or facies study (at the right bank of the Bhagirathi) shows four distinct layers (Figure 3). Approximately $2 \mathrm{~m}$ thick interfluve deposit exposed on the right bank has four distinct sedimentary layers, namely L1 - mud $(0.4 \mathrm{~m}), \mathrm{L} 2-$ silt with mud $(0.6 \mathrm{~m})$, L3 - micaceous sand $(0.7 \mathrm{~m})$ and L4 $\mathrm{mud} / \mathrm{clay}(0.3 \mathrm{~m})$. The multiple layers of river bank reflect various prominent and discontinuous semitemporary sedimentary structures. The upper layer L1 has laminated discontinuous litho-structure with prominent activities of living organisms while L2 bears prominent horizontal alignment of silt and mud with activities of plants and animals. The most vulnerable L-3 is composed of irregular micaceous sand that is not well-integrated due to the presence of bird's burrows (nests). In general, the fluctuation of water level with maximum velocity is confined within L-2, L-3 and L-4 layers. The 

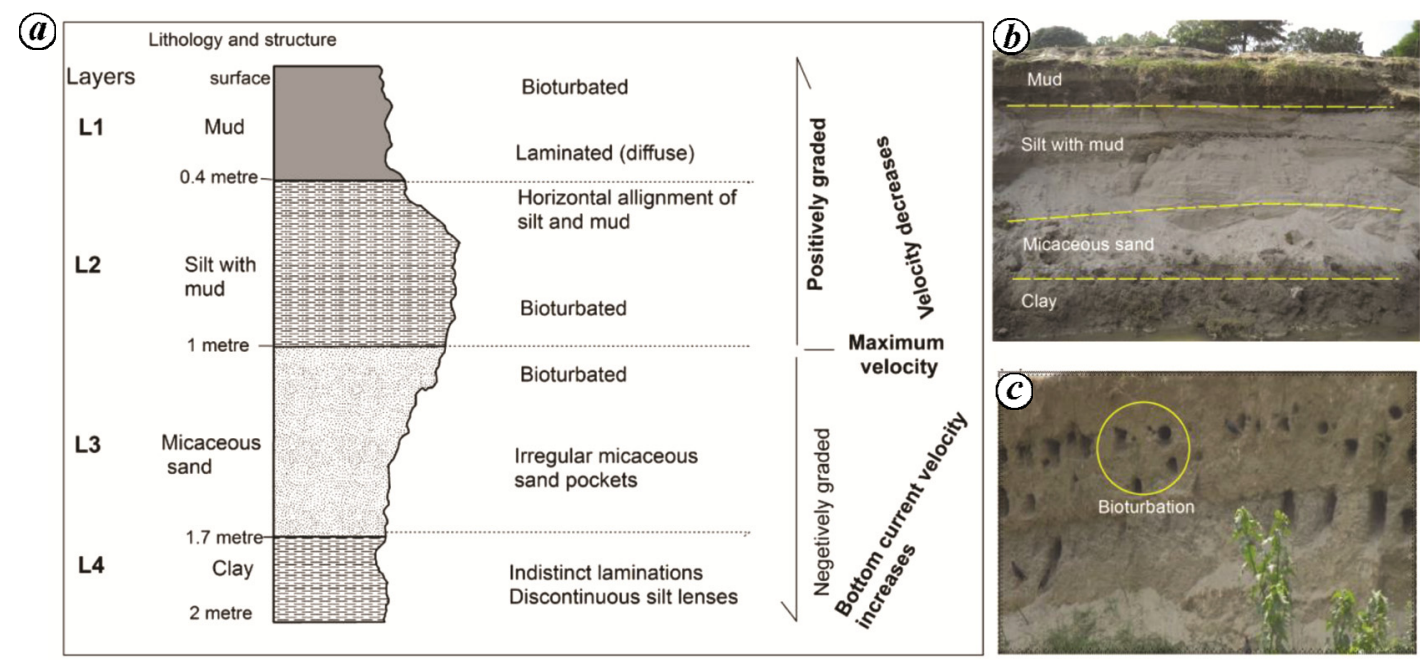

Figure 3. a, Quaternary sedimentary river bank facies. b, Prominent layers with micro sedimentary structures. $\boldsymbol{c}$, Micro burrows and bird nest on the vertical right bank of River Bhagirathi at Natungram village.

low-velocity current helps deposit large amounts of mica in the suspension condition, whereas high-velocity current helps bring mica-free fine sand within the lamination at low depth ${ }^{29}$.

Several fluvio-hydrological factors (helical flow, hydraulic action, cavitation, velocity fluctuation, discharge, lateral and vertical sediment accretion) help to erode within the dynamic concave bank site and simultaneously accelerate bank failure. The non-cohesive, highly bioturbated irregular micaceous sand layer is responsible for bank erosion as well as increasing the concavity of the right bank. The water flow with high velocity causes erosion at the bank toe on the part of non-cohesive soil layer (sand). The erosion at the bank toe steepens the bank height that decreases the bank stability, and also erosion of non-cohesive layer results in repeated bank failure.

Lastly, the river bank facies study focuses on rapid rate of lateral migration of the Bhagirathi (concave right bank near Natungram) towards River Babla due to the presence of discontinuous non-cohesive bank materials on the New Quaternary site.

\section{Shifting of course of River Bhagirathi through overlay analysis}

Revenue Survey map of 1852-55 (1 inch $=4$ miles; Figure $4 a$ ) clearly indicates that the interfluve distance (Table 2) between the two rivers was $1712.70 \mathrm{~m}$ at Chargobalpur. During the land revenue survey in 1852-55, confluence of River Babla was situated near Shiruli and a large meander loop of $11.2 \mathrm{~km}$ with elongated point bars were formed along both banks of the Bhagirathi (Figure $4 a$ ). During that period, the average width of the rivers was $485 \mathrm{~m}$ (Bhagirathi) and $275 \mathrm{~m}$ (Babla).
A significant point bar was also developed along the left bank of the Bhagirathi near the confluence point of River Babla. There was no depositional bar within the course of River Babla, which clearly reflects moderate sinuous channel pattern (SI value of 1.2). On the other hand, the sinuosity of River Bhagirathi followed a meandering course which was far greater (SI value of 1.7) compared to River Babla. Huge amounts of quaternary alluvium deposit within the course of River Bhagirathi reveal the possibility of cut-off formation on the left side of the more active stream.

US Army Map of 1956 (1:250,000) (Figure $4 b$ ) shows that the interfluve distance was $296.86 \mathrm{~m}$ near Chargobalpur and the average width of the rivers were $294.42 \mathrm{~m}$ (Bhagirathi) and $50.76 \mathrm{~m}$ (Babla). Due to formation of a mid-channel bar $(359,021.31$ sq. $\mathrm{m})$ within the course of River Bhagirathi, the flow had been diverted into two channels. The area (9.91 sq. $\mathrm{km}$ ) between the meander loop of Bhagirathi and Babla enclosed villages like Char Serpur, Sujapur, Char Sujapur, Raghupur, Bishnupur and Char Lakhuria. As a result near Kalyanpur, Bhagirathi ultimately captured Babla and the confluence point of the latter river had been shifted $(2.8 \mathrm{~km})$ towards upstretch from Shiruli to Kalyanpur Ghat. Similarly, sinuosity values of both the streams indicate meandering and sinuous (2.09 for Bhagirathi and 1.1 for Babla) channel patterns.

Landsat image of 1973 (spatial resolution $60 \mathrm{~m}$ shows Figure $4 c$ ) shows that the interfluve distance was $634.60 \mathrm{~m}$ at point $\mathrm{A}$ with the average width of $250 \mathrm{~m}$ for the Bhagirathi and $140 \mathrm{~m}$ for the Babla. As big cut-off is formed on the floodplain of River Bhagirathi, the value of sinuosity has reduced suddenly from 2.09 to 1.60 . Neck and chute cut-off are the most important causes of avulsion as well as one special form of channel avulsion that reduces channel length by cutting across the neck creating a chute at the vicinity of a point bar ${ }^{1}$. Low channel 
Table 2. Minimum distance between Bhagirathi and Babla rivers (1852-2017)

\begin{tabular}{lccccccc}
\hline Year & 2017 & 2009 & 2000 & 1991 & 1973 & 1956 & 1852 \\
\hline Minimum interfluve distance (m) & 46.28 & 137.32 & 200.00 & 241.00 & 334.64 & 1465.03 & 804.48 \\
\hline
\end{tabular}
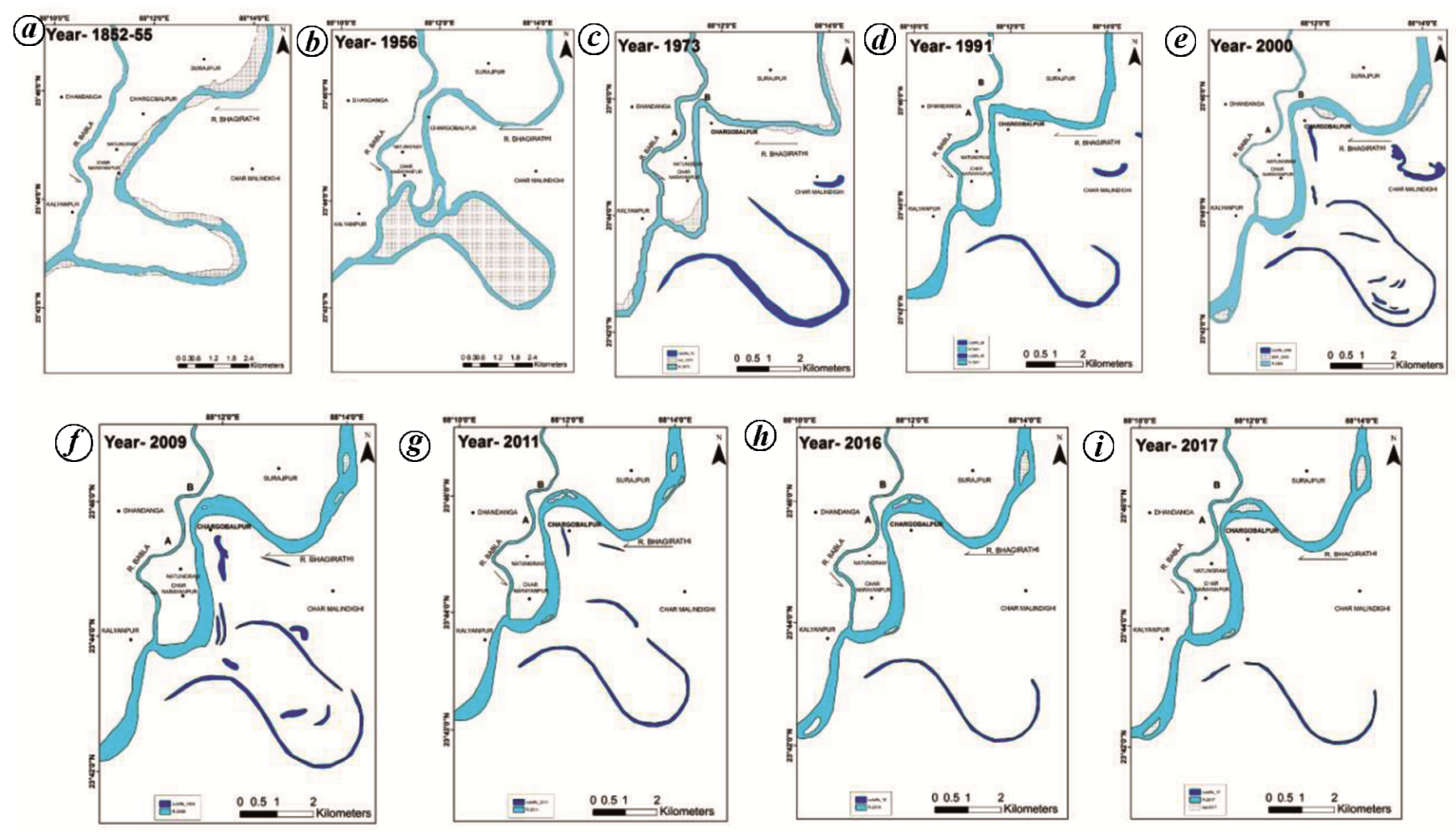

Figure 4. Shift of Bhagirathi channel between 1852 and 2017 near Natungram. (a) Revenue Survey Map of $1852-55$. (b) US Army map of 1956. $(\boldsymbol{c}-\boldsymbol{i})$ Landsat Images of (c) 1973, (d) 1991, (e) 2000, (f) 2009, (g) 2011, (h) 2016 and (i) 2017.

slope, shear stress and channel-bed aggradation create high sinuosity and ultimately form channel cut-offs. Due to formation of downstream aggradation bars, super elevation or fluctuation of water level with subsequent channel bank overflow creates channel diversion within the floodplain ${ }^{30}$. The shortest interfluve distance was $102 \mathrm{~m}$ near Chargobalpur (Bhagirathi meander loop) at point B in 1973.

Landsat image of 1991 (spatial resolution $30 \mathrm{~m}$; Figure $4 d$ ) shows that the shortest interfluve distance was $241 \mathrm{~m}$ at point $\mathrm{A}$, which had been shifted from point $\mathrm{B}$ to $\mathrm{A}$ within a time span of 18 years. The average width of rivers Bhagirathi and Babla was 208 and $133 \mathrm{~m}$ respectively, in 1991 at point $\mathrm{A}$. The sinuosity value of River Bhagirathi $(\mathrm{SI}=5)$ designates meandering pattern, and Babla was also a moderately meandering channel $(\mathrm{SI}=1.2)$. Previous channel bars within the course of River Bhagirathi were partially dissected and submerged below the water surface due to catastrophic floods in South Bengal in the consecutive years of 1978 and 1987, and flood-like situation in 1988.
Landsat image of 2000 (spatial resolution 30 m; Figure $4 e$ ) shows that the minimum interfluve distance was $200 \mathrm{~m}$ at point $\mathrm{A}$, which had reduced by almost $41 \mathrm{~m}$ from the previous image (1991). Average width was $140 \mathrm{~m}$ (Bhagirathi) and $108 \mathrm{~m}$ (Babla) in 2000. Further, three new mid-channel bars were exposed within course of River Bhagirathi at upstretch of Chargobalpur and below the confluence point.

Landsat image of 2009 (spatial resolution 30 m; Figure $4 f$ ) shows that the average distance was $137.32 \mathrm{~m}$ at point A. Therefore, a distance of about $63 \mathrm{~m}$ has reduced between the consecutive studied years of 2000 and 2009, and the average width of rivers Bhagirathi and Babla was 145.33 and $73.68 \mathrm{~m}$ respectively, at Chargobalpur. As the upper layer of the previous exposed mid-channel bars were being dissected, they had partially disappeared. The curvature of river Bhagirathi slightly increased $(\mathrm{SI}=1.52)$ from the previously followed path, but river Babla still maintained its moderately meandering course ( $\mathrm{SI}=1.25)$.

Figure $4 g-i$ shows landsat images of 2011, 2016 and 2017 respectively (spatial resolution $30 \mathrm{~m}$ ). Maps have 


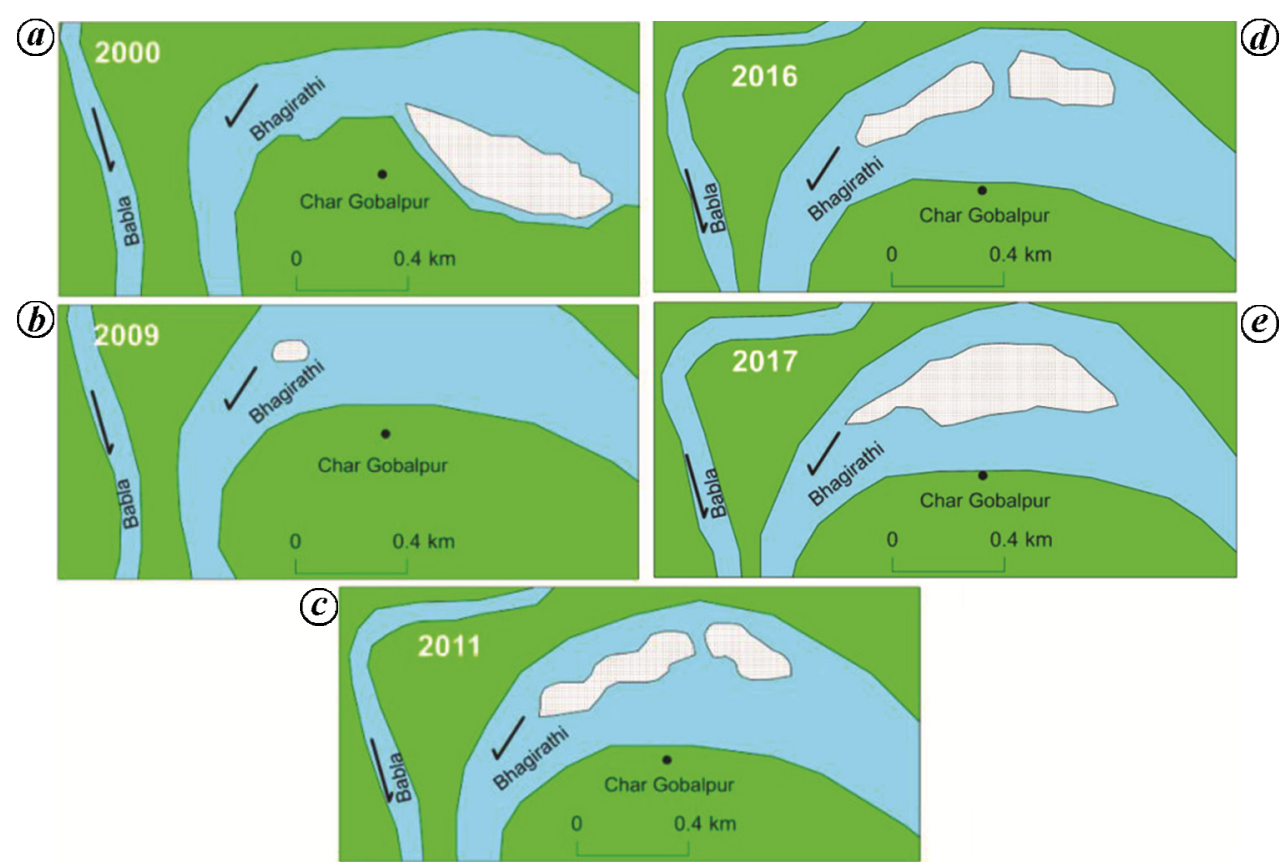

Figure 5. Temporal evolution of mid-channel bar within the course of River Bhagirathi. $\boldsymbol{a}$, Location of former bar near Chargopalpur (Landsat 2016). b. Newly formed mid-channel bar near Dhandanga (Landsat 2009). c. Two mid-channel bars formed with larger extent within the channel (Landsat 2011). $\boldsymbol{d}$, Growth of mid-channel bars (Landsat 20016). $\boldsymbol{e}$, Mid-channel bars merged together forming a single, larger-sized mid-channel bar (Landsat 2017).

also been prepared for 2011 and 2016 from Landsat images, but no significant change was detected. In 2017, the Bhagirathi (Figure $4 i$ ) showed phenomenal change after 2009 within its stretch. The interfluve distance (Table 2) was $46.28 \mathrm{~m}$ which is remarkably reduced from 2009. In 2017, the sinuosity value of River Bhagirathi was 1.45, whereas River Babla had sinuosity value of 1.25 in the same year. Within this temporal period of eight years, the main River Bhagirathi has shifted approximately $91.04 \mathrm{~m}$ towards River Babla and the annual rate of shifting was $11.38 \mathrm{~m}$. Extensive field studies during 2009-2017 shows the previous dissected submerged midchannel bars further separately exposed on the surface. In 2017, the isolated mid-channel bars merged and occupied a larger area within the flow path of River Bhagirathi. Due to rapid rate of bank scouring, the micaceous sand layer was being removed and the clay bed suddenly collapsed within the course of River Bhagirathi. One type of local bird species makes permanent nests through burrows within the sand layer, which accelerates the bank erosion process. As a result the strength of this layer is being reduced due to excessive stress on the bank materials. Every year the acre of acre interfluve agricultural lands (Natungram) are being engulfed within the course of River Bhagirathi, and this river is migrating towards River Babla.

From the overlay analysis of satellite images and old maps from 1852 to 2017 , it can be clearly stated that the average rate of shifting of River Bhagirathi towards River Babla is $5.3 \mathrm{~m} /$ year. However, in between 1973 and 2017, the rate had increased to $6.5 \mathrm{~m} /$ year. A big neck cut-off was also formed on the neighbouring floodplain at Kalyanpur between 1956 and 1973. During 1852-2017, there was a drastic change within the course of River Bhagirathi, and the channel thalweg is being gradually shifted due to the formation of previous point bar and present mid-channel bar. In recent decades, the rate of shifting of River Bhagirathi is $9 \mathrm{~m}$ /year, which is remarkable change and there is high probability to capture River Babla in the near future.

\section{Study of fluvial dynamics of Bhagirathi and Babla rivers}

From 2000 to 2017, extensive studies show that the highest monsoon discharge was 3951.44 and 2661.00 cumec (at Kalyanpur and Chargobalpur respectively) of River Bhagirathi, whereas 884.68 and 577.80 cumec (at Kalyanpur and Chargobalpur respectively) was the average monsoon discharge of River Babla. From 2000 to 2017, monsoonal average discharge of River Bhagirathi was 3500 and 2300 cumec, whereas for River Babla it was 780 and 500 cumec at Kalyanpur and Chargobalpur respectively. River Bhagirathi maintains rhythmic monsoon and post-monsoon discharge due to continuous water supply from the tributaries and parent River Ganga through Feeder Canal. In case of River Babla, the average post-monsoon discharge is comparatively lower because most of the non-perennial tributaries are linked with this river. Above $4 \mathrm{~m}$ hydraulic radius value with high velocity 
RESEARCH ARTICLES
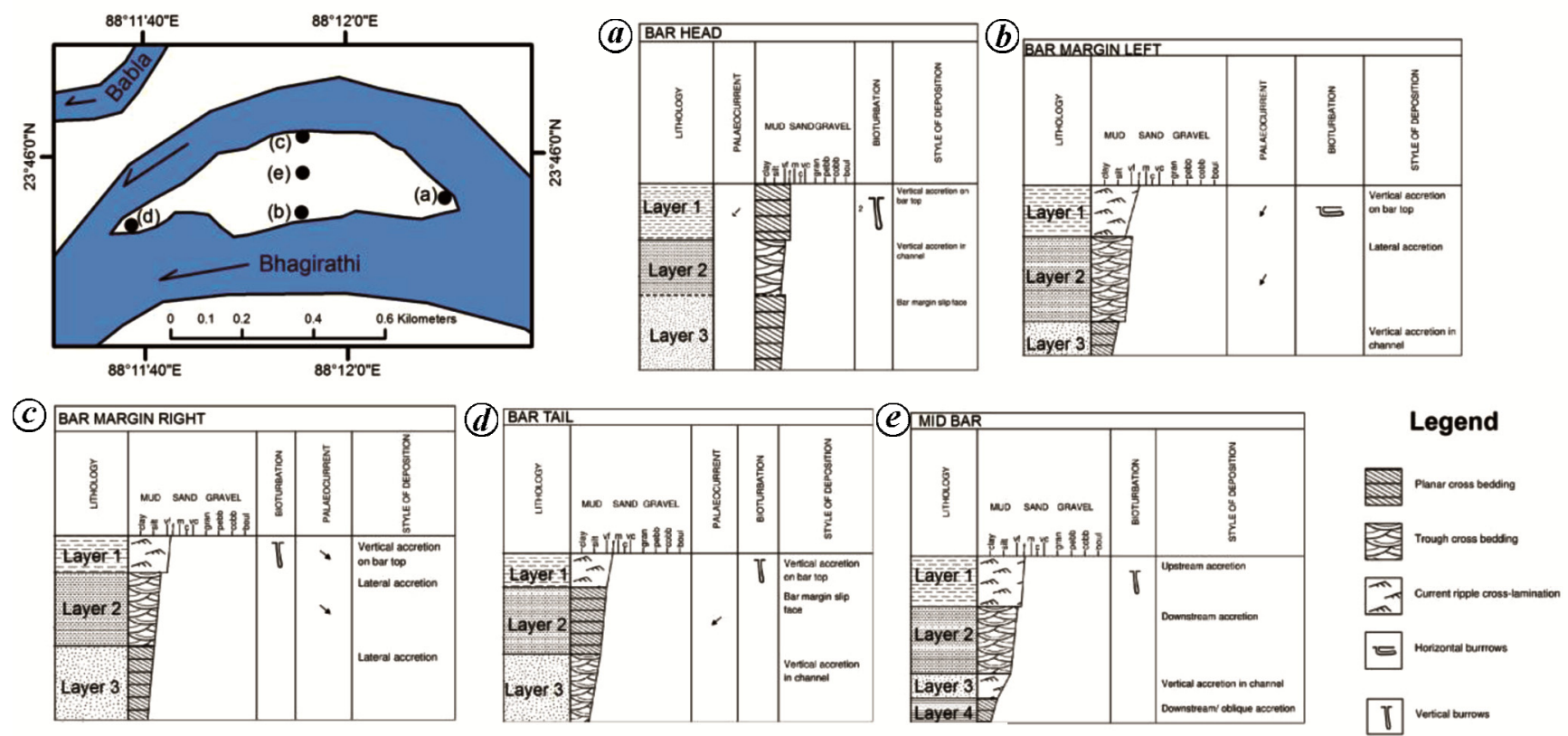

Figure 6. Location of sedimentary log sites on mid-channel bar. $\boldsymbol{a}$, Sedimentary log of bar head. $\boldsymbol{b}$, Sedimentary log of bar margin left. $\boldsymbol{c}$, Sedimentary log of bar margin right. $\boldsymbol{d}$, Sedimentary log of bar tail. $\boldsymbol{e}$, Sedimentary log of mid bar.

Table 3. Spatio-temporal growth of mid-channel bars (width, length and area)

\begin{tabular}{lccr}
\hline Year & Width $(\mathrm{m})$ & Length $(\mathrm{m})$ & Area (sq. m) \\
\hline 2017 & 248 & 945 & $164,700.41$ \\
2016 & 122 & 391 & 999.18 \\
& 104 & 529 & $57,732.77$ \\
2011 & 141 & 309 & 3753.90 \\
& 115 & 583 & $64,123.20$ \\
2009 & 79 & 146 & 8559.31 \\
\hline
\end{tabular}

$(1.9 \mathrm{~m} / \mathrm{s})$ also indicates that River Bhagirathi is highly energetic and has high capacity during the monsoon period (July-September). The average depth of River Bhagirathi (12 m) was three times greater than River Babla (4 m) in 2000. Now due to rapid rate of siltation the depth has been reduced, but is still double $(9.20 \mathrm{~m})$ with respect to Babla (4.2 m). The alluvial River Bhagirathi carries high suspended sediment load (average $42 \mathrm{mg} / \mathrm{l})$, whereas River Babla brings low sediment load (average $12 \mathrm{mg} / \mathrm{l}$ ) during the monsoon months. The noncohesive bank materials (at the concave bend of the Bhagirathi) help erode the right bank, and repeated slumping and cantilever failures have also occurred due to rapid rate of toe erosion with helical flow generated a few metres beyond the mid-channel bar within the course of River Bhagirathi.

\section{Evolution of mid-channel bar and its stability}

Mid-channel bar evolution: Formation of mid-channel bar vis-à-vis flow separation is a normal fluvial architectural rhythm in any meandering channel. Landsat image of 2000 shows that an elongated mid-channel bar $(816 \mathrm{~m}$ long, $236 \mathrm{~m}$ wide and 0.13 sq. $\mathrm{km}$ area) was situated along the left bank and almost $300 \mathrm{~m}$ away from the present mid-channel bar (Figure 5).

The bar had been dissected due to devastating flood in September 2000. After a few years, a new small midchannel bar was exposed on the surface which was located along the right bank of the Bhagirathi in front of the shortest interfluve section. Vertical and horizontal accretion processes are being accelerated at a tremendous rate due to obstruction. The 2009 image clearly shows that a small, 8559.31 sq. $\mathrm{m}$ bar had been traced within the channel. After two years, another small bar had emerged above the old bar ( 3753.90 sq. $\mathrm{m}$ ), and the previous bar had grown in size and occupied an area of $64,123.20$ sq. $m$ (Table 3). Within five years, both the bars became elongated in shape due to vertical and horizontal accretion and thalweg line had been shifted from left to right side. In year 2017, image shows that the previous two bars joined together and finally formed a large elongated bar. It had almost $945 \mathrm{~m}$ length, $348 \mathrm{~m}$ width and $0.16 \mathrm{sq} . \mathrm{km}$ coverage area. As the main flow has been shifted towards the right bank, the non-cohesive bank materials are being collapsed in the channel path of River Bhagirathi due to the amalgamation of different fluvio-hydrological processes working at the converged zone (different flow directions merged at a particular point).

\section{Stability of mid-channel bar through sedimentary $\log$ study}

The first sedimentary log at bar head shows three prominent horizons, namely vertical accretion on bar top, 
second vertical accretion in the channel and lowermost bar margin slip face. Vertical accretion or deposition of sediments on bar top layer showed prominent planner crossed stratification structure, whereas trough cross-stratification structure was confined within the channel adjacent layer (Figure 6). Subsequently, prominent planner stratification structure was found within the sublayer due to lateral accretion. The trough cross-lamination structure was noticed within the channel sand bodies due to the continuous process of bank scouring and sediment-laden flood water ${ }^{31}$.

Sedimentary log of left and right bar margins shows distinct litho structures like current ripple cross-lamination, trough cross-bedding and planar cross-bedding from layer 1 to layer 3 . In both cases, vertical accretion on top layer and underlay lateral accretion have occurred. Similarly, vertical accretion was also found in channel adjacent layer in both cases. Biological activities of both plants and animals have been reflected on the top layers of left and right bar margins. Mid-bar sedimentary log was subdivided into four indistinct layers, such as upstream accretion, downstream accretion, vertical accretion in channel and downstream oblique accretion. These accretions in case of mid bar have been observed from the imprint of palaeo current. Lowermost layer is prominently characterized by planner crossed-stratification in discontinuous manner. Bar tail sedimentary log study shows three distinct irregular layers such as vertical accretion on bar top, bar margin slip face and vertical accretion in channel respectively. Dynamic fluvio-hydrological variables as well as monsoonal flood water help make ripple cross-stratification, planner lamination and trough crossstratification in different layers. The comprehensive five sedimentary logs study assemblage reveal high stability of the mid-channel bar, rapid rate forward accretion and thalweg line shifting towards right bank side of the River Bhagirathi. As a result, bank failure aggravates the rapid rate of stream capture possibilities.

\section{Conclusion}

Image overlay, fluvial dynamics, bank facies and sedimentological litholog studies concluded that dynamic fluvio-hydrological variables and quaternary deposit cause the rapid progression of lateral shifting of River Bhagirathi towards River Babla at Natungram. The average lateral shifting rate of River Bhagirathi towards river Babla from 1852 to 2017 was $5.3 \mathrm{~m} /$ year, but during 1973-2017 the rate had been increased to $6.5 \mathrm{~m} /$ year, although in the last two decades from 2000 to 2017 , the average rate of shifting has increased to $9 \mathrm{~m} /$ year. In 2017, the interfluve distance was $46 \mathrm{~m}$ approximately. If the Bhagirathi maintains its average shifting rate at $9 \mathrm{~m} /$ year then it will capture River Babla within five years. Right bank facies study clearly showed that noncohesive bank materials help accelerate bank failure and continuous interfluve encroaching tendency. The study of mid-channel bar evolution, stability and thalweg line shifting also clearly reflected that the mid-channel bar is getting stabilized. Both vertical and horizontal accretions are directly influencing the shifting of thalweg line towards right bank of Bhagirathi or towards the interfluve. Mid-channel bar separates flow direction and ultimately two flow directions converge at the right bank side, where continuous bank failure happens. It accelerates bank concavity as well as River Bhagirathi is shifting towards River Babla.

1. Allen, J. R., A review of the origin and characteristics of recent alluvial sediments. Sedimentology, 1965, 5(2), 89-191; https:// doi.org/10.1111/j.1365-3091.1965.tb01561.x.

2. Jain, V. and Sinha, R., Fluvial dynamics of an anabranching river system in Himalayan foreland basin, Baghmati river, north Bihar plains, India. Geomorphology, 2004, 60(1-2), 147-170; https:// doi.org/10.1016/j.geomorph.2003.07.008.

3. Jones, L. S. and Schumm, S. A., Causes of avulsion: an overview. In Fluvial Sedimentology VI, Blackwell Science, Oxford, UK, 1999, vol. 28, pp. 171-178; https://books.google.co.in/books?hl= en $\& 1 \mathrm{r}=\& \mathrm{id}=\mathrm{k} 9 \mathrm{rsR} 2 \mathrm{MmvVsC} \& \mathrm{oi}=\% 20 \mathrm{fnd} \& \mathrm{pg}=\mathrm{PA} 171 \& \mathrm{dq} \# \mathrm{v}$

4. Törnqvist, T. E. and Bridge, J. S., Spatial variation of overbank aggradation rate and its influence on avulsion frequency. Sedimentology, 2002, 49(5), 891-905; https://doi.org/10.1046/j.13653091.2002.00478.x.

5. Jain, V. and Sinha, R., Hyperavulsive-anabranching Baghmati river system, north Bihar plains, eastern India. Z. für Geomorphol., 2003, 47(1), 101-116; https://www.schweizerbart.de/ papers/zfg/detail/47/64552/Hyperavulsive anabranching_Baghmati_river_system $\mathrm{n}$

6. Slingerland, R. and Smith, N. D., Necessary conditions for a meandering-river avulsion. Geology, 1998, 26(5), 435-438; https://doi.org/10.1130/0091-7613(1998)026<0435:NCFAMR $>2.3$. $\mathrm{CO} ; 2$.

7. Aslan, A., Autin, W. J. and Blum, M. D., Causes of river avulsion: insights from the late Holocene avulsion history of the Mississippi River, USA. J. Sediment. Res., 2005, 75(4), 650-664; https://doi. org/10.2110/jsr.2005.053.

8. Stouthamer, E. and Berendsen, H. J., Avulsion: the relative roles of autogenic and allogenic processes. Sediment. Geol., 2007, 198(3-4), 309-325; https://doi.org/10.1016/j.sedgeo.2007.01.017.

9. Blair, T. C. and McPherson, J. G., Historical adjustments by Walker River to lake-level fall over a tectonically tilted halfgraben floor, Walker Lake Basin, Nevada. Sediment. Geol., 1994, 92(1-2), 7-16; https://doi.org/10.1016/0037-0738(94)00058-1.

10. Dumont, J. F., Neotectonics and rivers of the Amazon headwaters. In The Variability of Large Alluvial Rivers (eds Schumm, S. A. and Winkley, B. R.), ASCE Press, New York, USA, 1994, pp. 103-113.

11. Harbor, D. J., Schumm, S. A. and Harvey, M. D., Tectonic control of the Indus River in Sindh, Pakistan. In The Variability of Large Alluvial Rivers (eds Schumm, S. A. and Winkley, B. R.), ASCE Press, New York, USA, 1994, pp. 161-175.

12. Smith, N. D., McCarthy, T. S., Ellery, W. N., Merry, C. L. and Rüther, H., Avulsion and anastomosis in the panhandle region of the Okavango Fan, Botswana. Geomorphology, 1997, 20(1-2), 49-65; https://doi.org/10.1016/S0169-555X(96)00051-7.

13. Schumm, S. A., Schumm, S. A., Dumont, J. F. and Holbrook, J. M., Active Tectonics and Alluvial Rivers, Cambridge University Press, Cambridge, UK, 2002; https://books.google.co.in/ books?hl=en\&lr=\&id=yTc3jmYKS6EC\&oi=fnd\&pg=PR11\&dq 
RESEARCH ARTICLES

14. Mertes, L. A., Dunne, T. and Martinelli, L. A., Channel-floodplain geomorphology along the Solimões-Amazon river, Brazil. Geol. Soc. Am. Bull., 1996, 108(9), 1089-1107; https://doi.org/ 10.1130/0016-7606(1996)108<1089:CFGATS $>2.3$. CO;2

15. Latrubesse, E. M. and Rancy, A., The late Quaternary of the Upper Juruá River, southwestern Amazonia, Brazil: geology and vertebrate paleontology. Quat. South Am. Antarctic Peninsula, 1998, 11(2)

16. Latrubesse, E. M. and Franzinelli, E., The late Quaternary evolution of the Negro River, Amazon, Brazil: implications for island and floodplain formation in large anabranching tropical systems. Geomorphology, 2005, 70(3-4), 372-397; https://doi.org/10. 1016/j.geomorph.2005.02.014.

17. Valente, C. R. and Latrubesse, E. M., Fluvial archive of peculiar avulsive fluvial patterns in the largest Quaternary intracratonic basin of tropical South America: the Bananal Basin, CentralBrazil. Palaeogeogr., Palaeoclimatol., Palaeoecol., 2012, 356, 62-74; https://doi.org/10.1016/j.palaeo.2011.10.002.

18. Törnqvist, T. E., Wallinga, J., Murray, A. S., De Wolf, H., Cleveringa, P. and De Gans, W., Response of the Rhine-Meuse system (west-central Netherlands) to the last Quaternary glacio-eustatic cycles: a first assessment. Global Planet. Change, 2000, 27(1-4), 89-111; https://doi.org/10.1016/S0921-8181(01)00072-8.

19. Wells, N. A. and Dorr Jr, J. A., Shifting of the Kosi river, northern India. Geology, 1987, 15(3), 204-207; https://doi.org/10.1130/ 0091-7613(1987)15<204:SOTKRN>2.0.CO;2.

20. Törnqvist, T. E., Middle and late Holocene avulsion history of the River Rhine (Rhine-Meuse delta, Netherlands). Geology, 1994, 22(8), 711-714; https://doi.org/10.1130/0091-7613(1994)022< 0711:MALHAH>2.3.CO;2.

21. Johnson, S. Y. and NurAlam, A. M., Sedimentation and tectonics of the Sylhet trough, Bangladesh. Geol. Soc. Am. Bull., 1991, 103(11), 1513-1527; https://doi.org/10.1130/0016-7606(1991) 103<1513:SATOTS $>2.3 . \mathrm{CO} ; 2$.

22. Gupta, N., Kleinhans, M. G., Addink, E. A., Atkinson, P. M. and Carling, P. A., One-dimensional modeling of a recent Ganga avulsion: assessing the potential effect of tectonic subsidence on a large river. Geomorphology, 2014, 213, 24-37; https://doi.org/ 10.1016/i.geomorph.2013.12.038.

23. Rudra, K., Dynamics of the Ganga in West Bengal, India (17642007): implications for science-policy interaction. Quaternary
Int., 2010, 227(2), 161-169; https://doi.org/10.1016/j.quaint. 2009.10.043.

24. Parua, P. K., The Ganga: Water use in the Indian Subcontinent, Springer Science and Business Media, Vol. 64, 2010, https://books. google.co.in/books?hl=en\&lr=\&id=yUc7Cus2a-MC\&oi=fnd\&pg= PR2\&dq.

25. Rudra, K., The Bhagirathi-Hugli River System. In Rivers of the Ganga-Brahmaputra-Meghna Delta, Springer Cham., Switzerland, 2018, pp. 77-93; https://doi.org/10.1007/978-3-319-76544$\underline{06}$.

26. Karle, K. F. and Densmore, R. V., Stream and floodplain restoration in a riparian ecosystem disturbed by placer mining. Ecol. Eng., 1994, 3(2), 121-133.

27. Schumm, S. A., Erroneous perceptions of fluvial hazards. Geomorphology, 1994, 10(1-4), 129-138; https://doi.org/10.1016/ 0169-555X(94)90012-4.

28. Knighton, D., Fluvial Forms and Process, Edward Arnold Ltd, London, UK, 1984.

29. Paola, C. H. R. I. S., Wiele, S. M. and Reinhart, M. A., Upper-regime parallel lamination as the result of turbulent sediment transport and low-amplitude bed forms. Sedimentology, 1989, 36(1), 47-59; https://doi.org/10.1111/j.1365-3091.1989.tb00819.x.

30. Bryant, M., Falk, P. and Paola, C., Experimental study of avulsion frequency and rate of deposition. Geology, 1995, 23(4), 365-368; https://doi.org/10.1130/0091-7613(1995)023<0365:ESOAFA $>2.3$. $\mathrm{CO} ; 2 /$.

31. Fielding, C. R., Fluvial channel and overbank deposits from the Westphalian of the Durham coalfield, NE England. Sedimentology, 1986, 33(1), 119-140; https://doi.org/10.1111/j.1365-3091. 1986.tb00748.x.

ACKNOWLEDGEMENTS. We thank the Director, Geological Survey of India for assistance. We also thank the Chairman, Kolkata Port Trust, for providing valuable information regarding River Bhagirathi.

Received 6 June 2018; revised accepted 21 May 2019

doi: $10.18520 / \mathrm{cs} / \mathrm{v} 117 / \mathrm{i} 4 / 662-671$ 